\title{
EVALUATION OF THE PHBS PROGRAM FOR 2018, 2019, AND 2020 IN MASALLE VILLAGE, ENREKANG REGENCY
}

\author{
Haderiah $^{1}$, Muhammad Ikbal Arif ${ }^{2}$, La Taha ${ }^{3}$, Sulasmi $^{4}$, Hidayat ${ }^{5}$ \\ Department of Environmental Health Poltekkes Ministry of Health Makassar, \\ Indonesia \\ Email: haderiah.nuru64@gmail.com², mikbalarif@gmail.com², \\ mikbalarif@gmail.com ${ }^{3}$, laksmi.kesling@gmail.com ${ }^{4}$, risikolingkungan@gmail.com ${ }^{5}$
}

\begin{tabular}{|c|c|}
\hline ARTICLE INFO & ABSTRACT \\
\hline $\begin{array}{l}\text { Received: } \\
\text { January, 26 } \\
2022 \\
\text { Revised: } \\
\text { February, } 17^{\text {th }} \\
2022 \\
\text { Approved: } \\
\text { February, } 18^{\text {th }} \\
2022\end{array}$ & $\begin{array}{l}\text { PHBS is all healthy behaviors that are carried out on the } \\
\text { basis of awareness to help themselves and family members } \\
\text { in the health sector and can play an active role in carrying } \\
\text { out public health activities. Clean culture is a reflection of } \\
\text { people's attitudes and behavior in maintaining and } \\
\text { maintaining personal and environmental hygiene in } \\
\text { everyday life. The PHBS indicators that are the center of this } \\
\text { research are healthy latrines, clean water supply, hand } \\
\text { washing with soap, and smoking habits. This study aims to } \\
\text { evaluate the PHBS program in the village of Masalle, } \\
\text { Enrekang Regency. This type of research is a descriptive } \\
\text { research which describes, discloses and presents what is in } \\
\text { accordance with the data and facts regarding the PHBS } \\
\text { program that has been launched. The number of samples } \\
\text { was } 4 \text { PHBS indicators, namely healthy latrines, clean water } \\
\text { supply, washing hands with soap, and smoking habits.The } \\
\text { results obtained from the results of the PHBS study in } \\
\text { Masalle Village, namely in 2018, the indicators for healthy } \\
\text { latrines were 94.0\%, PAB was 100\%, CTPS was 99.1\%, } \\
\text { smoking habits were 53.3\%. In 2019 the indicators for } \\
\text { healthy latrines were 94.8\%, PAB was 100\%, CTPS was } \\
100 \% \text { smoking habits were 53.3\%. In 2020 the indicators } \\
\text { for healthy latrines are 95.3\%, PAB is, CTPS is 100\%, } \\
\text { smoking habits are 53.3\%. }\end{array}$ \\
\hline
\end{tabular}

\begin{tabular}{ll}
\hline KEYWORDS & PHBS, Evaluation, Successful, Unsuccessful \\
\hline & Haderiah, Muhammad Ikbal Arif, La Taha, Sulasmi, Hidayat. (2022). \\
& Evaluation of The PHBS Program for 2018, 2019, and 2020 in \\
& Masalle Village, Enrekang Regency. Journal Eduvest. Vol 2(2): 286- \\
How to cite: & 296 \\
E-ISSN: & $2775-3727$ \\
Published by: & https://greenpublisher.id/
\end{tabular}




\section{INTRODUCTION}

PHBS are all healthy behaviors that are carried out on the basis of awareness to help themselves and family members in the health sector and can play an active role in carrying out public health activities (Depkes RI, 2010). Clean and Healthy Living Behavior also referred to as PHBS is a set of behaviors that are practiced on the basis of awareness as a result of learning from a person, family, group or community who is able to help themselves in the health sector and play an active role in realizing public health (Ministry of Health RI, 2011). To improve PHBS for everyone is not an easy thing but requires a process to influence each other, interact and socialize between individuals, groups and monitor, assess and measure the level of development of all arrangements. Therefore, fostering and empowering PHBS is carried out through an orderly approach, namely the arrangement of households, public places, workplaces and schools (Central Java Provincial Health Office, 2009 in Ahmad Z, 2016).

Based on data obtained in the village of Masalle, in the community there are still villages that have not ODF (open defecation free) or stop defecation where this focuses on public awareness to no longer open defecation (Pertiwi, Arif, \& Haderiah, 2021). In addition, in terms of washing hands using soap in Masalle village, there are still people who are not accustomed to washing hands with soap before and after carrying out activities, then in terms of providing clean water, in terms of quantity the amount of clean water supply is sufficient, but during the dry season the community has difficulty getting clean water because in Masalle village there is no access to water, the PDAM, the community only uses water from springs or mountain water. Then in the PHBS program, the scope of the smoking habit of the people in Masalle village, there are still many people who have the habit of smoking in the house (Kalumbi, Thaulo, MacPherson, \& Morse, 2020).

The habit of people who still defecate openly can lead to environmental contamination, especially in water sources that are close to where people defecate openly (Purnama \& Susanna, 2020). With the PHBS program in Masalle village conducted by the Puskesmas in the working area of Masalle village, it can support this research to evaluate the success of the PHBS program that has been carried out, namely Stop open defecation, provide clean water, wash hands with soap, and smoke. In the evaluation of the PHBS program, it was carried out to see whether in the village of Masalle, Kab. Enrekang which is the center of this research has been carried out well or how the level of success is due to the condition of the village that has not been ODF and how the level or success of the PHBS indicators are being implemented. Based on the data obtained that there are still people who do not have family latrines and are still open defecation, this research was carried out to see whether the PHBS program was running according to the expectations and plans of the Masalle Health Center, Enrekang Regency.

\section{RESEARCH METHOD}

The type of research used in this study is to use descriptive research methods, which to evaluate the PHBS program from 2018, 2019, and 2020 using data sourced from the Masalle Health Center, Enrekang Regency (Pertiwi et al., 2021). Descriptive research 
is to describe, reveal and present what is in accordance with the data, facts and reality regarding the PHBS program that has been planned (Khalid, De la ROsa, \& Fikre, 2020).

The research location is located in the village of Masalle kab. Enrekang, Research time is divided into two stages, namely the research preparation stage and the research activity stage. The preparation stage where the preparation of the research proposal is then carried out in the research stage.The population in this study is data from the Masalle Health Center from 2018, 2019, and 2020. The samples in this study were PHBS indicators that were carried out in Masalle village, namely healthy latrines, clean water supply, CTPS, and smoking habits.

The data in this study are secondary data, obtained through direct data collection at the Masalle Health Center and literature from the library or other readings that are closely related to the writing of this research. Data analysis was carried out using tables, graphs, and percentage analysis to see the success rate of the PHBS program from 2018-2020 then analyzed descriptively.

\section{RESULT AND DISCUSSION}

\section{Results}

Table 1 Recapitulation of PHBS Study Results in Masalle Village in 2018

\begin{tabular}{ccccc}
\hline 2018 & $\begin{array}{c}\text { healthy } \\
\text { latrine }(\%)\end{array}$ & $\begin{array}{c}\text { Provision of } \\
\text { Clean Water } \\
(\%)\end{array}$ & $\begin{array}{c}\text { wash hands } \\
\text { with soap (\%) }\end{array}$ & $\begin{array}{c}\text { Smoking } \\
\text { habit (\%) }\end{array}$ \\
\hline $\begin{array}{c}\text { Triwulan } \\
1\end{array}$ & 95.2 & 100 & 98.6 & 52.9 \\
\hline $\begin{array}{c}\text { Triwulan } \\
2\end{array}$ & 95.2 & 100 & 98.6 & 52.9 \\
\hline $\begin{array}{c}\text { Triwulan } \\
3\end{array}$ & 92.9 & 100 & 99.5 & 53.3 \\
\hline $\begin{array}{c}\text { Triwulan } \\
4\end{array}$ & 92.9 & 100 & 100 & 54.3 \\
\hline Total & $\mathbf{3 7 6 . 2}$ & $\mathbf{4 0 0}$ & $\mathbf{3 9 6 . 7}$ & $\mathbf{2 1 3 . 4}$ \\
\hline $\begin{array}{c}\text { Rata- } \\
\text { rata }\end{array}$ & $\mathbf{9 4 . 0}$ & $\mathbf{1 0 0}$ & $\mathbf{9 9 . 1}$ & $\mathbf{5 3 . 3}$ \\
\hline
\end{tabular}

Source: Secondary Data, 2018 (Masalle Health Center)

Based on table 1 recapitulation of the results of the PHBS study in Masalle village in 2018, the highest percentage of data is on the clean water supply (PAB) indicator which reaches an average of $100 \%$ while the lowest is on the smoking habit indicator, where people still have a smoking habit, especially smoking. inside the house. This can be seen from the percentage of indicators of smoking habits which have an average of $53.3 \%$. People who no longer smoke in the house and no longer have a smoking habit are $53.3 \%$ of the results of data collection conducted by the Masalle Health Cent 
Table 2 Recapitulation of PHBS Study Results in Masalle village in 2019

\begin{tabular}{ccccc}
\hline 2019 & $\begin{array}{c}\text { healthy latrine } \\
(\%)\end{array}$ & $\begin{array}{c}\text { Provision of } \\
\text { Clean Water } \\
(\%)\end{array}$ & $\begin{array}{c}\text { wash hands } \\
\text { with soap (\%) }\end{array}$ & Smoking habit (\%) \\
\hline Triwulan 1 & 93.8 & 100 & 100 & 54.8 \\
\hline Triwulan 2 & 95.2 & 100 & 100 & 53.8 \\
\hline Triwulan 3 & 95.2 & 100 & 100 & 52.9 \\
\hline Triwulan 4 & 95.2 & 100 & 100 & 53.3 \\
\hline Total & $\mathbf{3 7 9 . 4}$ & $\mathbf{4 0 0}$ & $\mathbf{4 0 0}$ & $\mathbf{2 1 4 . 8}$ \\
\hline Rata-rata & $\mathbf{9 4 . 8}$ & $\mathbf{1 0 0}$ & $\mathbf{1 0 0}$ & $\mathbf{5 3 . 7}$ \\
\hline
\end{tabular}

Source: Secondary Data, 2019 (Masalle Health Center)

Based on table 2 recapitulation of the results of the PHBS study in Masalle village in 2019, the highest percentage of data is on the indicators of clean water supply (PAB) and CTPS which have an average percentage of $100 \%$. While the indicator of smoking habits is still the lowest percentage, namely $53.7 \%$. People who no longer smoke in the house and no longer have a smoking habit increased by $53.7 \%$ from the results of data collection conducted by the Masalle Health Center.

Table 3 Recapitulation of PHBS Study Results in Masalle Village in 2020

\begin{tabular}{cccccc}
\hline No & Hamlet Name & Total number of KK & $\begin{array}{c}\text { Number of } \\
\text { latrines }\end{array}$ & $\begin{array}{c}\text { Number of } \\
\text { households with } \\
\text { latrine access }\end{array}$ \\
\hline 1 & Lo,ko & 169 & 103 & 159 & $94 \%$ \\
\hline 2 & Katonan Padang & 120 & 59 & 66 & $55 \%$ \\
\hline 3 & Panggandangan & 249 & 130 & 137 & $55 \%$ \\
\hline 4 & Patekkong & 206 & 112 & 119 & $58 \%$ \\
\hline
\end{tabular}

Source: Secondary Data, 2020 (Masalle Health Center)

Based on table 3 recapitulation of the results of the PHBS study in Masalle village in 2020, the highest percentage is still on the PAB and CTPS indicators, which reach an average of $100 \%$. While the indicator of smoking habits is still at the lowest percentage, but in 2020 it has increased by a percentage of $54.4 \%$. People who no longer smoke in

\begin{tabular}{ccccc}
\hline 2020 & $\begin{array}{c}\text { Jamban sehat } \\
(\%)\end{array}$ & $\begin{array}{c}\text { Provision of Clean Water } \\
\text { wash hands with soap (\%) }\end{array}$ & $\begin{array}{c}\text { Kebiasaan } \\
\text { Merokok (\%) }\end{array}$ \\
\hline Triwulan 1 & 91.4 & $1 \%)$ & 100 & 53.3 \\
\hline Triwulan 2 & 94.0 & 100 & 100 & 53.8 \\
\hline Triwulan 3 & 97.6 & 100 & 100 & 56.1 \\
\hline Triwulan 4 & 98.5 & 100 & 100 & 54.7 \\
\hline Total & $\mathbf{3 8 1 . 5}$ & $\mathbf{4 0 0}$ & $\mathbf{4 0 0}$ & $\mathbf{2 1 7 . 9}$ \\
\hline Rata-rata & $\mathbf{9 5 . 3}$ & $\mathbf{1 0 0}$ & $\mathbf{1 0 0}$ & $\mathbf{5 4 . 4}$ \\
\hline
\end{tabular}

the house and no longer have a smoking habit increased by $54.4 \%$ from the results of data collection conducted by the Masalle Health Center.

Table 4 Distribution of Data on Ownership of Healthy Latrine in Masalle Village in 2018

Source: Secondary Data, 2018 (Masalle Health Center)

Table 5 Distribution of Health Latrine Ownership Data in Masalle Village in 2019

\begin{tabular}{cccccc}
\hline No & Hamlet Name & $\begin{array}{c}\text { Total number of } \\
\text { KK }\end{array}$ & $\begin{array}{c}\text { Number of } \\
\text { latrines }\end{array}$ & $\begin{array}{c}\text { Number of } \\
\text { households with } \\
\text { latrine access }\end{array}$ \\
\hline 1 & Lo,ko & 169 & 103 & 159 & $94 \%$ \\
\hline 2 & Katonan Padang & 120 & 61 & 68 & $57 \%$ \\
\hline 3 & Panggandangan & 249 & 133 & 140 & $56 \%$ \\
\hline 4 & Patekkong & 206 & 112 & 119 & $58 \%$ \\
\hline
\end{tabular}

Source: Secondary Data, 2018 (Masalle Health Center) 
Table 6 Distribution of Health Latrine Ownership Data in Masalle Village in 2020

\begin{tabular}{cccccc}
\hline No & Hamlet Name & $\begin{array}{c}\text { Total number of } \\
\text { KK }\end{array}$ & $\begin{array}{c}\text { Number of } \\
\text { latrines }\end{array}$ & $\begin{array}{c}\text { Number of households } \\
\text { with latrine access }\end{array}$ & $\%$ \\
\hline 1 & Lo,ko & 183 & 150 & 174 & $95 \%$ \\
\hline 2 & Katonan Padang & 110 & 76 & 103 & $94 \%$ \\
\hline 3 & Pangaandangan & 195 & 142 & 183 & $94 \%$ \\
\hline 4 & Patekkong & 211 & 131 & 190 & $90 \%$ \\
\hline
\end{tabular}

Source: Secondary Data, 2018 (Masalle Health Center)

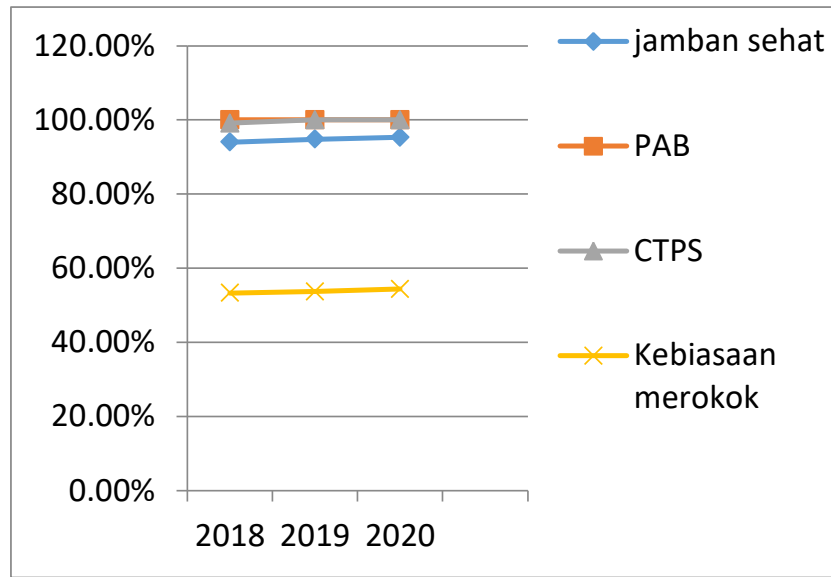

Figure 1 Maslle Village PHBS Data Chart 2018, 2019, and 2020

Source: Secondary Data, 2018,2019,2020 (Masalle Health Center)

\section{Discussion}

According to (Kitivo \& Kavulya, 2021) program evaluation is an effort to gather information about the work of government programs as an appropriate alternative in making a decision. The purpose of program evaluation is as a tool to improve planning and implementation of future programs (Glasgow et al., 2019). Program evaluation is also to determine the level of implementation of a policy carefully by knowing the effectiveness of each component (Hudson, Hunter, \& Peckham, 2019). Evaluation of the process is focused on implementing the program, whether it is in accordance with the predetermined plan or not (Van Melle et al., 2019). The assessment also aims to determine whether the chosen method is effective or ineffective (Naqvi, Arshad, Farooq, \& Nadeem, 2020).

Masalle Village is one of the villages located in Masalle District, Enrekang Regency (Pertiwi et al., 2021). This research center is located at the Masalle Health Center, Buntu Sarong Village, Masalle District, Enrekang Regency(Rustan \& Hasriani, 2020). The Masalle Health Center is a community health center which has 6 villages as the working area of the Masalle Health Center which includes the Masalle village.

There are 10 indicators of PHBS in the household setting, namely childbirth assisted by health workers, exclusive breastfeeding, weighing infants and toddlers regularly, using clean water, washing hands with soap, using healthy latrines, eradicating mosquito larvae, eating fruits and vegetables every day, physical activity, and not smoking in the house. However, the focus of this research is the 4 PHBS indicator variables, namely healthy latrines, washing hands with soap, providing and using clean water, and not smoking in the house.

After observing and collecting data at the Masalle Health Center, annual PHBS data from the last 3 years, 2018, 2019, and 2020. The success and failure of the PHBS program can be seen from the percentage of each indicator each year. Members or in the field of Health Promotion at the Masalle Community Health Center carry out community 
empowerment and data collection every 3 months in Masalle District including Masalle village.

\section{Healthy latrine}

Based on 2018 data, the healthy latrine indicator reached $94.0 \%$, in 2019 the percentage of PHBS data on the healthy latrine indicator increased from $94.0 \%-94.8 \%$ until in 2020 it increased to $95.3 \%$. This is influenced because many people have healthy latrines, although there are still people who ride in latrines owned by neighbors or their families. However, this is categorized as people using healthy latrines and not defecating indiscriminately (Januariana, 2022).

One of the factors that influence the success of the PHBS program on healthy latrine indicators is the existence of counseling and community empowerment, especially in the village of Masalle. People who have received counseling or information from the Health Promotion of the Masalle Health Center will better understand and know the importance of defecating in place and maintaining environmental cleanliness as well as personal hygiene so that people avoid all kinds of diseases. This will support the level of public health to increase (Metzler, Sanders, Rusby, \& Crowley, 2012).

The availability of healthy latrine facilities and infrastructure (family latrine ownership) also supports the success of a PHBS program in the community. Based on the availability of latrine infrastructure that meets the requirements in the community is one of the things that support the success of a program that continues to increase. According to the Indonesian Ministry of Health (2004), healthy latrines that meet the requirements include:

a. Do not pollute drinking water sources, the location of the reservoir is 1015 meters from drinking water sources.

b. Odorless and feces can not be touched by insects or mice.

c. It is wide enough and sloping/sloping towards the squat hole so as not to pollute the surrounding soil.

d. Easy to clean and safe to use.

e. Equipped with protective walls and roofs, waterproof walls and colors.

f. Enough light

g. waterproof floor

h. Ventilation is quite good

i. Water and cleaning tools available

The ownership of latrines and the use of latrines are factors that influence the success of a PHBS program on healthy latrine indicators where the percentage increases every year. This is in line with Viska's (2016) research which increased after the program was implemented. Based on Viska's research (2016), the results of his research stated that the distribution of environmental-based disease frequency 2 weeks before the one million latrine program was $6.1 \%$ and 2 weeks after the one million latrine program was $0 \%$. The distribution of the frequency of stool disposal patterns before the one million latrine program was in the bad category $(100 \%)$, while after the program it was in the bad category $(22.4 \%)$. Utilization of latrines program one million latrines that have been used $77.6 \%$ and $22.4 \%$ which have not been utilized.

The success of a program in the community, especially the PHBS program in Masalle village, if the community has understood and implemented each PHBS indicator properly and correctly. If the community already has the knowledge, attitudes and actions to carry out clean and healthy living behavior in daily life, then one of the benchmarks for the success of the PHBS program can be said to be successful. The success rate of a PHBS program is successful if each indicator continues to increase every year. 
People who already know about the dangers of open defecation will take advantage of the healthy latrines they have or use healthy latrines owned by their family and neighbors so that the potential for open defecation will not occur.

People who already know and then run a clean and healthy lifestyle in their daily lives, especially defecating in healthy latrines will be more protected from all kinds of diseases that are transmitted through feces. The community already has the knowledge and attitudes that underlie them not to open open defecation, although there are still people who are negligent and indifferent to the use of healthy latrines. This is indicated by people who ride or use latrines belonging to their families or neighbors sometimes still defecate carelessly because they do not have their own healthy latrines.

There are many factors that cause people to not have family latrines, one of which is economic factors. People who have a poor economy are still not able to make healthy family latrines so that people take advantage of or ride on people who already have their own healthy latrines.

1. Provision of Clean Water

Water is one of the most important needs in human life. In all the activities that humans do, they need the availability of water, especially clean water. For this reason, it is very important to provide clean water, so it is only natural that the clean water sector gets the main handling priority because it involves the lives of many people (Chrisiansen et al, 2015).

Masalle Village is one of the villages located in Maselle District where this village is located in the mountainous area of Enrekang Regency. Masalle village has not yet received clean water services from the PDAM of Enrekang Regency, so far the village community has relied on the pipeline network by utilizing natural resources, namely from mountain springs. 80\% of the area in Enrekang Regency is located in mountainous areas, one of which is Masalle village. In terms of the physical quality of water in the village of Masalle, water sourced from mountain springs has the characteristics of being odorless, tasteless, and colorless. However, the clean water from these mountains contains little lime content, this can happen because naturally the water will contain mineral substances that come from the soil and rocks.

In the indicator of clean water supply in Masalle village, the percentage continues to reach $100 \%$. The main source of clean water for the Masalle village community, Masalle District, is from mountain springs. In terms of quantity, the community is no longer worried about the supply of clean water because during the rainy season there is a lot of water sourced from the mountains, and so is the case during the dry season, the quantity of water for the people of Masalle village is included in the category of meeting the needs of the community every day.

In the village of Masalle, the quality of clean water used daily meets physical qualities, namely tasteless, odorless, and colorless. Meanwhile, in terms of the quantity of water sources owned, they are sourced from mountain springs, where we know that the nature of mountain water flows continuously so that the water needs of the community in Masalle Village are well met.

Clean water must have special requirements so that the water does not cause disease for humans, because water is a drinking need (including for cooking) for humans themselves. Conditions for healthy water include (Catur dkk,2019) :

a. Physical requirements: colorless, tasteless, and odorless

b. Bacteriological requirements: water for healthy drinking must be free from all bacteria, especially pathogenic bacteria. 
c. Healthy drinking water must contain certain substances in certain amounts. Lack or excess of chemicals in water will cause physiological disturbances in humans such as arsenic, copper, iron, organic substances and $\mathrm{pH}$.

In providing clean water, especially for drinking water, it is necessary to pay attention to three important aspects, namely the quality of raw water, the amount of raw water, and the continuity of raw water.(Ronny, 2017).

2. Wash your hands with soap

The PHBS indicator, namely CTPS, is also included in the program launched by the Masalle Health Center. Washing hands with soap is an important thing that must be done especially before eating, processing food, and after activities outside and inside the room. In the observations at the Masalle Health Center that have been carried out, the CTPS percentage data in 2018 is $99.1 \%$, in 2019 and 2020 the CTPS percentage data has reached $100 \%$.

One of the factors that influence the continued increase in the indicator for hand washing with soap is the COVID-19 pandemic, which makes people wash their hands more often using soap and clean water.(Amuakwa-Mensah, Klege, Adom, \& Köhlin, 2021) In addition to washing hands using soap and running water, implementing a clean and healthy lifestyle is also an action to prevent the spread of the COVID-19 virus.(Sahira, Hasanah, \& Nasution, 2021) The people of Masalle village have understood and carried out this individual cleaning activity. The community already knows that washing hands with soap and using clean water is done before preparing and processing food, after gardening and raising livestock.

Not washing hands with soap and running water can cause all kinds of diseases for a person, including worms. Many factors cause helminthiasis, such as not washing hands before eating, not washing hands with soap and running water after defecating, not washing hands before and after serving food, and not washing hands with soap and running water after gardening or raising livestock.

The increasing percentage data from 2018, 2019, and 2020 which reached 100\%, indicates that the people in the village of Masalle have understood and practiced a clean and healthy lifestyle by washing their hands with soap before and after activities outside and inside the room. This is in line with Jusi's research (2013), where the evaluation of the Community-Based Total Sanitation Program in Gowah Hamlet, Kedung Sumber Village, Balong Panggang District, Gresik Regency on pillar 2, namely hand washing with soap (CTPS) increased from $18.3 \%$ to $98.3 \%$. .

3. Smoking Habits

In the PHBS indicator, namely smoking habits, in the village of Masalle the data shows that smoking behavior in the community is still very high. Smoking is one of the things that is very difficult to remove from society. In society, the family plays an important role in improving the quality of community health because in it there is an interaction between fellow family members (Heni dkk,2017).

In the PHBS program in Masalle village which is still the lowest indicator and is still a health problem in general, smoking is the habit, where the percentage of data obtained in 2018 is 53.3\%, 2019 is $53.7 \%$, and in 2020 there is a slight increase that is $54.4 \%$. The highest result is $54.4 \%$, indicating that some people no longer have the habit of smoking, especially not smoking in the house.(Exposto et al., 2022) However, there are still around $45.6 \%$ of people who find it difficult and even unable to get rid of this smoking habit.

Many factors make it difficult for people to eliminate smoking behavior or habits, including the knowledge factor.(Exposto et al., 2022) If people have knowledge about the dangers and bad consequences of smoking, especially smoking inside the house, near 
pregnant women and in public places, then people will always protect themselves from this smoking habit. If there are still people who make the habit of smoking in the house then this is not in accordance with one of the indicators of PHBS, where everyone should not smoke, especially when close to pregnant women, babies and in public places (Heni dkk,2017).

Smoking habits, especially smoking indoors will be very dangerous for people who smoke and also people who are exposed to cigarette smoke in the vicinity. Many diseases that can arise caused by cigarette smoke, one of which is ARI. Based on research by Nur Aini Cora (2020), the average smoking place for family members who smoke is inside the house. Having one or more smokers in the house will increase the risk of family members suffering from illness, such as respiratory problems, worsening asthma and can increase the risk of getting an ARI attack, especially in toddlers (Nur Aini Cora et al, 2020).

Smoking is not allowed in the room or in the house intended so as not to make other family members as passive smokers which are harmful to health. Because in one cigarette that is smoked will release about 4,000 harmful chemicals such as nicotine, tar and carbon monoxide (CO) (Nenes, 2017).

In addition to knowledge of the dangers of smoking, environmental factors are also one of the factors that make it difficult for people to eliminate smoking behavior. The people of Masalle village are the majority of vegetable farmers, so the reason people find it difficult to eliminate smoking behavior is because according to their response they can work more strongly and do their main activities for farmers. In addition, the village of Masalle is located in the mountains which is in fact very cold. The cold mountain environment makes the villagers of Masalle use smoking as their body warmer.

Cigarettes contain ingredients that make it difficult for a person to quit smoking or become addicted to smoking. People's attitudes that are difficult to change in carrying out clean and healthy living behaviors are a challenge for health workers themselves. In Selvin's research (2017), internal and external factors are also factors that influence people's clean and healthy living behavior. Internal factors are traits inherited from parents and traits that arise because of an impulse based on needs. External factors are factors from the individual plus other external factors such as the surrounding environment.

Many things are a challenge for the health promotion (health promotion) at the Masalle Health Center so that one of the indicators of PHBS is not successful, namely cigarettes. Environmental conditions that make it difficult for some people to get rid of this smoking habit. This is due to cold weather conditions. In addition, if the health promotion party conducts outreach or data collection in the community, they think that they will receive assistance from the government related to the absence of family latrines in their homes. The knowledge and economic factors of the community are also a challenge so that the PHBS program is not successful in the household setting.

Based on the research of Dewi, et al (2016), based on the recapitulation of PHBS data in 2012 - 2014 there has been a drastic decline in the achievement of the PHBS Program in Karangturi Village, East Semarang District, Semarang City. The results showed that the responsiveness of the PHBS Program had been able to run according to the target, namely Karangturi village PHBS \% in 2012 was $97.36 \%$, in 2013 was $99.23 \%$, and in 2014 was $99.70 \%$. Based on the existing data, it can be seen that the achievement of PHBS households continues to increase from 2012 to 2014. So it can be said that the public health status is increasing from the previous year. 


\section{CONCLUSION}

Based on the results of research with 4 PHBS variables studied regarding the PHBS Program Evaluation in 2018, 2019, and 2020 in the village of Masalle, Enrekang Regency, it can be concluded that: Before the PHBS program was launched, there were still many people who did not know how to live a clean and healthy life, after the PHBS program was launched, people have made more and more habits of living clean and healthy in their daily life. Evaluation of the PHBS program in the village of Masalle in 2018, 2019, and 2020 the scope of healthy latrines is said to be successful because the percentage continues to increase in 2018 to 2020. Evaluation of the PHBS program in the village of Masalle in 2018, 2019, and 2020 the scope of clean water supply is said to be successful because the percentage in 2018, 2019, and 2020 continues to increase to $100 \%$. Evaluation of the PHBS program in the village of Masalle in 2018, 2019, and 2020 the scope of hand washing with soap is said to be successful because it continues to increase until it reaches 100\%. Evaluation of the PHBS program in Masalle village in 2018, 2019, and 2020 the scope of smoking habits is said to be successful because the percentage in 2018, 2019, and 2020 has increased and some have eliminated smoking habits.

\section{REFERENCES}

Amuakwa-Mensah, Franklin, Klege, Rebecca Afua, Adom, Philip Kofi, \& Köhlin, Gunnar. (2021). COVID-19 and handwashing: Implications for water use in sub-Saharan Africa. Water Resources and Economics, 36, 100189.

Exposto, Levi Anatolia S. M., Pacheco, Cipriano do R., Maia, Januario M., da Cruz, Oscar Seixas, Cravalho, Honoria de F., Pereira, Santiago J., \& de Oliveira, Felisbela A. O. (2022). THE ROLE OF HEALTH PROMOTION IN CHANGE TEENAGE SMOKING BEHAVIOR. Indonesian Journal of Multidisciplinary Science, 1(4), 347-363.

Glasgow, Russell E., Harden, Samantha M., Gaglio, Bridget, Rabin, Borsika, Smith, Matthew Lee, Porter, Gwenndolyn C., Ory, Marcia G., \& Estabrooks, Paul A. (2019). RE-AIM planning and evaluation framework: adapting to new science and practice with a 20 -year review. Frontiers in Public Health, 7, 64 .

Hudson, Bob, Hunter, David, \& Peckham, Stephen. (2019). Policy failure and the policy-implementation gap: can policy support programs help? Policy Design and Practice, 2(1), 1-14.

Januariana, Neni Ekowati. (2022). Factors That Influence Community Behavior Of Incidental Defeat at Desa Jawa Belakang, Kecamatan Langsa, Kota Langsa. International Archives of Medical Sciences and Public Health, 3(1), $75-85$.

Kalumbi, Limbani R., Thaulo, Chisomo, MacPherson, Eleanor E., \& Morse, Tracy. (2020). Perspectives and practices on water, sanitation, and hygiene from a fishing community along Lake Malombe, Southern Malawi. International Journal of Environmental Research and Public Health, 17(18), 6703. 
Khalid, Muhammad, De la ROsa, Denisse, \& Fikre, Belay. (2020). Enhancing environmental sustainability in slow fashion apparel industry: risk identification and supply chain mapping of bio-based polymer fibers.

Kitivo, Ezekiel M., \& Kavulya, Joseph Muema. (2021). Evaluation of Training Programmes. International Journal of Educational Theory and Practice, 4(1-4), 1-16.

Metzler, Carol W., Sanders, Matthew R., Rusby, Julie C., \& Crowley, Ryann N. (2012). Using consumer preference information to increase the reach and impact of media-based parenting interventions in a public health approach to parenting support. Behavior Therapy, 43(2), 257-270.

Naqvi, Sohail Ali, Arshad, Masood, Farooq, Assad, \& Nadeem, Farah. (2020). Implementation of Sustainable Practices in Textile Processing Mills of Lahore, Pakistan. Polish Journal of Environmental Studies, 29(1).

Pertiwi, Angghi, Arif, Muh Ikbal, \& Haderiah, Haderiah. (2021). Evaluation Of The Phbs Program For 2018, 2019, And 2020 In Masalle Village, Enrekang Regency. Urban Health, 3(1).

Purnama, Sang Gede, \& Susanna, Dewi. (2020). Hygiene and sanitation challenge for covid-19 prevention in Indonesia. Kesmas: Jurnal Kesehatan Masyarakat Nasional (National Public Health Journal).

Rustan, Edhy, \& Hasriani, Hasriani. (2020). Communication pattern between nurses and elderly patients through a neuro-linguistic programming approach. Jurnal Studi Komunikasi, 4(1), 75-89.

Sahira, Audila, Hasanah, Utia Rizka, \& Nasution, Arifah Farhah. (2021). Overview of Compliance Implementation of Public and Community Health Protocol Implementation on Effort to Break the Chain of Transmission of the Covid-19 Virus. International Archives of Medical Sciences and Public Health, 2(2), 224-234.

Van Melle, Elaine, Frank, Jason R., Holmboe, Eric S., Dagnone, Damon, Stockley, Denise, Sherbino, Jonathan, \& Collaborators, International Competency based Medical Education. (2019). A core components framework for evaluating implementation of competency-based medical education programs. Academic Medicine, 94(7), 1002-1009. 